\title{
El paisaje en la cinematografía: la costa de Llanes (Asturias) en la obra de José Luis Garci
}

\author{
Pedro Javier Millán Barroso \\ Departamento de Información y Comunicación de la Universidad de Extremadura \\ Carmen Rodríguez Pérez \\ Departamento de Geografía de la Universidad de Oviedo \\ Juan Sevilla Álvarez \\ Departamento de Geografía de la Universidad de Oviedo
}

RESUMEN:

En un contexto de creciente consideración del paisaje como un bien público, reafirmado por trabajos científicos, divulgativos e institucionales, el papel de la producción cinematográfica es relevante debido a su alcance espacial y sociocultural, en tanto que fuente de información, documental y pedagógica, y como vehículo propagador de representaciones del territorio con impronta en el imaginario colectivo. Este artículo analiza la imagen paisajística de la costa de Llanes filmada por José Luis Garci en El abuelo (1998), You're the one (2000) e Historia de un beso (2002), como hito reciente en la divulgación del paisaje del litoral oriental de Asturias ${ }^{1}$.

\section{PALABRAS CLAVE:}

Paisaje, Cinematografía, Llanes, Asturias, José Luis Garci.

\section{ABSTRACT:}

In a context where landscape is increasingly considered as a public good, reaffirmed by scientific, informative and institutional works, the role of film production is relevant because of its spatial and sociocultural scope, as an informative, documentary or pedagogical source, and also for spreading landscape representations that mark the collective imagination. This article studies the landscape image of Llanes filmed by José Luis Garci in El abuelo (1998), You're the one (2000) and Historia de un beso (2002) as a recent landmark to extent the knowledge of eastern Asturias.

\section{KEYWORDS:}

Landscape, Cinematography, Llanes, Asturias, José Luis Garci.

\footnotetext{
Esta investigación se ha elaborado en el marco del proyecto de investigación «Paisajes patrimoniales de la España At-
} lántica y Navarra” (clave de referencia: CSO2012-39564-C07-05). 
1. Introducción: la mirada cinematográfica al paisaje

En la extensión contemporánea del concepto de patrimonio, donde es clave la voluntad de las colectividades de proteger y transmitir tanto manifestaciones valiosas de su memoria y de su cultura como los espacios en que se enraízan, interviene una renovada mirada al medio con especial atención a su componente natural y paisajístico ${ }^{1}$. En este contexto se subraya la importancia de expresiones y lugares con valores relevantes para la colectividad ${ }^{2}$. Y surge una nueva dimensión territorial del patrimonio $^{3}$ que concierne a espacios señalados por su representatividad, singularidad, rareza, estado de conservación, simbolismo, etc. Determinadas áreas reciben atención de agentes sociales, económicos, científicos e institucionales, ya sean locales o con otras procedencias, que identifican valores ecológicos, estéticos, pedagógicos, simbólicos, etc. Y promueven su conocimiento convencidos de que, por su interés o relevancia social, deben ser contemplados, valorados, compartidos y protegidos 4 .

En este contexto, interesa llamar la atención sobre la difusión del conocimiento del territorio en manifestaciones artísticas y culturales del período contemporáneo, sobre todo plásticas, escénicas y literarias, aportando a la divulgación de los paisajes la idea de composición socialmente construida sobre la base de

GUILLAUME, Marc, "Invention et stratégies du patrimoine", en Patrimoines en folie, Ministère de la Culture et de la Communication, Cahier 5, Édition de la Maison des Sciences de l'Homme, París, 1990, pp. 12-20, cf. p. 13; BERDOULAY, Vincent, "Requalification des lieux et des espaces publics à travers la réinvention des rapports à la nature", en Hégoa, no 24, Pau, 2004, pp. 9-10, cf. p. 9; BÉGHAIN, Patrice, Le patrimoine: culture et lien social, Presses de Science Po (La Bibliothèque du citoyen), París, 1998, 115 pp., cf. pp. 8, 59 y 65.

2 BOUISSET, Christine, DEGRÉMONT, Isabelle y SEVILLA, Juan, "Le patrimoine naturel vu du web: discours, valeurs, fonctions", en Sud-Ouest Européen. Revue Géographique des Pyrénées et du Sud-Ouest, n 30, Toulouse, 2010, pp. 85-98, cf. p. 86.

3 BERDOULAY, Vincent, "Les valeurs géographiques", en Encyclopédie de Géographie, Economica, París, 1992, pp. 385-403, cf. pp. 386-387; DEGRÉMONT, Isabelle, "Patrimoine et zone littorale, un renouveau des enjeux touristiques dans les Pyrénées Atlantiques”, en Sud-Ouest Européen, ${ }^{\circ}$ 1, Toulouse, pp. 33-46, cf. p. 35.

4 BOUISSET, Christine, DEGRÉMONT, Isabelle y SEVILLA, Juan, "Le patrimoine naturel...", opus cit., cf. p. 86. la contemplación o el disfrute escénico ${ }^{5}$. En efecto, la experiencia sensorial genera representaciones muy expresivas y reveladoras de los valores atribuidos a los lugares y de su interpretación social, económica y cultural. Tomando en consideración esta premisa, atender a la producción cinematográfica adquiere pleno sentido dado que, al igual que ocurre en la pintura paisajista y en la literatura de viajes o de ficción $n^{6}$, reproduce imágenes del territorio y, al mismo tiempo, evidencia la manera de concebir $\mathrm{y}$ aprovechar sus elementos y recursos naturales y antrópicos en marcos históricos y culturales concretos. En el caso del cine, además, proporciona imágenes dinámicas y en una cantidad no alcanzada por otros tipos de expresión artística.

Estudiar la representación del paisaje en la cinematografía está plenamente justificado si se toma en consideración su alcance espacial y su trascendencia sociocultural en una sociedad contemporánea cuyas percepciones del mundo, actitudes y tendencias, están cada vez más mediatizadas por la imagen ${ }^{7}$. El cine, bien sea

CAMARERO GÓMEZ, Gloria, "Paisaje, cine y vanguardias artísticas", en Visiones del paisaje: Actas del Congreso Visiones del Paisaje (Priego de Córdoba, 1997), Servicio de Publicaciones de la Universidad de Córdoba, Córdoba, 1999, pp. 235-243; RODRÍGUEZ BARBERÁN, Francisco Javier, "Las ciudades del espectador. El cine y la creación de un paisaje cultural contemporáneo", en PH Boletín del Instituto Andaluz del Patrimonio Histórico, Año no 13, nº 56, Sevilla, 2005, pp. 70-81, cf. pp. 71-72; DELGADO BUJALANCE, Buenaventura y OJEDA RIVERA, Juan Francisco, "La comprensión de los paisajes agrarios españoles. Aproximación a través de sus representaciones", en Boletín de la Asociación de Geógrafos Españoles, n51, Madrid, 2009, pp. 93-126, cf. p. 94; ESPEJO MARÍN, Cayetano, "El paisaje de Madrid en la obra de Antonio López García”, en Nimbus, n²9-30, Almería, 2012, pp. 217-232, cf. pp. 217-218. En relación con la noción de paisaje y su estudio en manifestaciones culturales y artísticas contemporáneas resulta asimismo de interés la Tesis Doctoral de Pedro Plasencia Lozano, en su capítulo 2 (pp. 31-136). Véase PLASENCIA LOZANO, Pedro, El paisaje de los puentes urbanos. La mirada del cine. El New Hollywood y Woody Allen, Tesis Doctoral disponible en Dehesa, Universidad de Extremadura, Cáceres, 2012, 881 pp. Recuperado de http://dehesa.unex.es/handle/10662/358 [consultado el 08/03/2017].

6 RODRÍGUEZ BARBERÁN, Francisco Javier, "Las ciudades del espectador...", opus cit., cf. p. 70; GÁMIR ORUETA, Agustín y MANUEL VALDÉS, Carlos, "Cine y Geografía: espacio geográfico, paisaje y territorio en las producciones cinematográficas", en Boletín de la Asociación de Geógrafos Españoles, n 45, Madrid, 2007, pp. 157-190, cf. pp. 159-161.

7 LÓPEZ JUAN, Aramis, "El cine español como fuente documental para el estudio de los barrios marginales", 


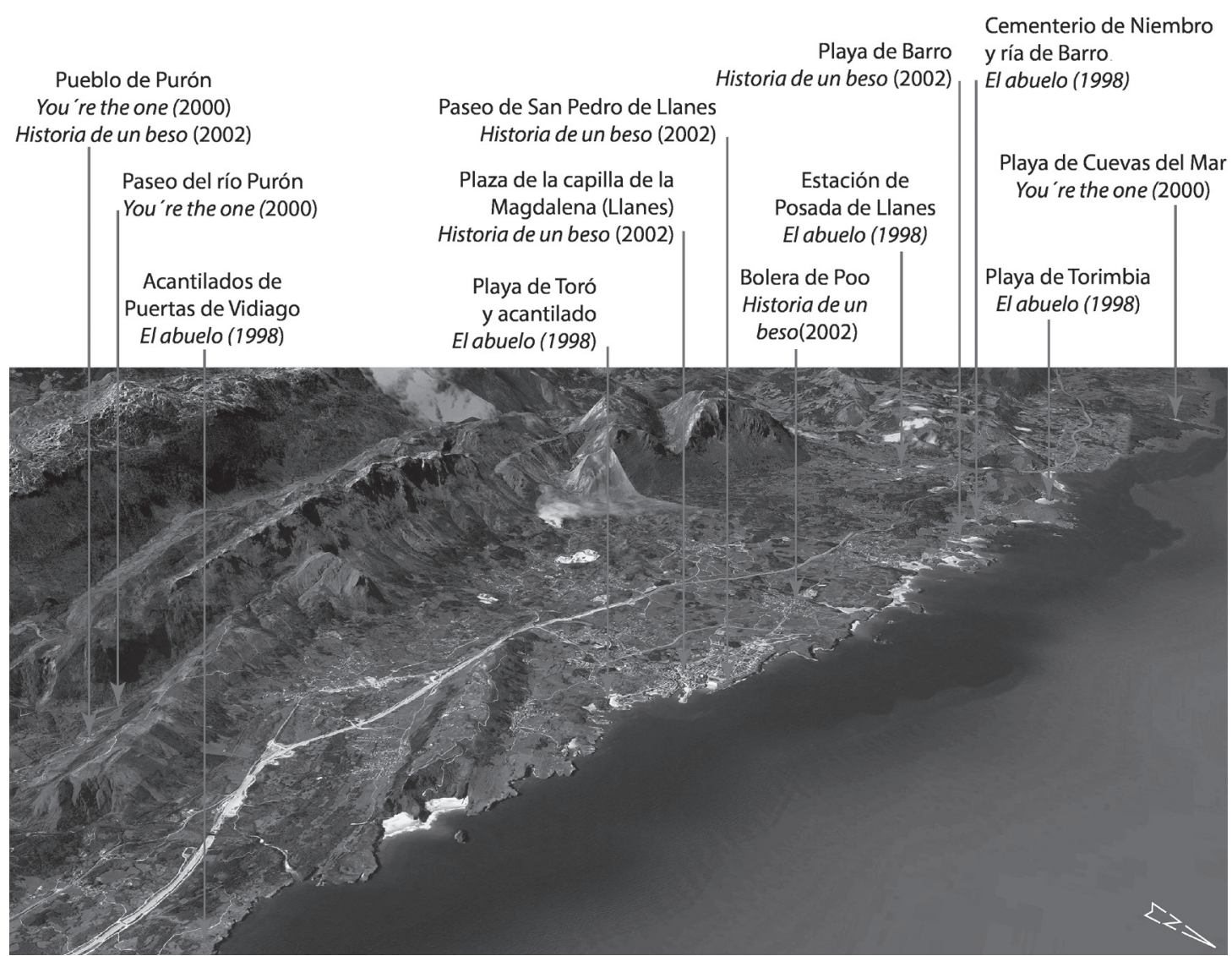

Fig. 1. Situación geográfica de los lugares seleccionados por José Luis Garci en el concejo de Llanes para El abuelo, You're the one e Historia de un beso (imagen de Google Earth de 2014).

documental o de ficción -con sus particulares finalidades- constituye una fuente de conocimiento de lugares tanto próximos como remotos, cotidianos o desconocidos, pretéritos y actuales. Conjuntamente, actúa como vehículo propagador de tomas de conciencia, incluida la valorización de distintos atributos del territorio $^{8}$, con una llamativa impronta en el imaginario colectivo al generar un amplio repertorio

en Investigaciones geográficas, $\mathrm{n}^{\circ} 47$, Alicante, 2008, pp. 139-157, cf. pp. 139 y 141; PLASENCIA LOZANO, Pedro, "Los puentes como argumento estético en la trilogía del hampa de Brian de Palma: El precio del poder, Los intocables de Eliot Ness y Atrapado por su pasado", en Norba-Arte, vol. XXX, Cáceres, 2010, pp. 227-246, cf. p. 228; NIETO CODINA, Aurelio, "Las ciudades en el cine de Alfred Hitchcock. Una aproximación a los estudios fílmicos desde el ámbito de la Geografía”, en Espacio, Tiempo y Forma. Serie VI, Nueva época. Geografía, no 4 y 5, Madrid, 2011-2012, pp. 123-140, cf. pp. 125-126.

8 LARA VALLE, Juan Jesús y GARCÍA RUIZ, Antonio Luis, "Cine y patrimonio urbano. El paisaje granadino en el imaginario del celuloide", en Ciudad, territorio y paisaje: reflexiones para un debate multidisciplinar, CSIC, Madrid, 2010, pp. 397-407, cf. pp. 393 y 397; de representaciones compartidas, y de alguna manera inculcadas (de forma intencionada o indirecta) en un número elevado de espectadores ${ }^{9}$. Para ello aprovecha técnicas propias, como el plano, el encuadre, la tonalidad y el sonido, aplicadas a aquellas características de los paisajes que se desea subrayar, aunque el propio argumento de la obra, la historia narrada y escenificada, contribuye a poner en valor los espacios en que se desarrolla la acción ${ }^{10}$.

PLASENCIA LOZANO, Pedro, "Los puentes como argumento...", opus cit., cf. p. 228.

9 RODRÍGUEZ BARBERÁN, Francisco Javier, "Las ciudades del espectador...”, opus cit., cf. pp. 70-72; GÁMIR ORUETA, Agustín y MANUEL VALDÉS, Carlos, "Cine y Geografía...”, opus cit., cf. pp. 159-161, 164 y 166; COSTA MAS, José, "Imaginarios fílmicos sobre la especulación y la corrupción asociadas a procesos de urbanización extensa", en Urbanismo expansivo: de la utopia a la realidad: comunicaciones: XXII Congreso de Geógrafos Españoles, Asociación de Geógrafos Españoles, Madrid, 2011, pp. 167-178, cf. p. 168; NIETO CODINA, Aurelio, "Las ciudades en el cine de...", opus cit., cf. p. 125.

10 LARA VALLE, Juan Jesús y GARCÍA RUIZ, Antonio Luis, “Cine y patrimonio urbano...”, opus cit., cf. p. 397 
El impacto de las imágenes del cine alcanza las esferas social, antropológica, histórica, geográfica y estética, configurando una suerte de cultura territorial capaz de estimular en los espectadores inquietud e interés por los lugares proyectados en la pantalla ${ }^{11}$. La producción cinematográfica, en origen mediatizada por la percepción que sus responsables tienen de las características del espacio, tiene la capacidad de influir en una experiencia contemporánea de ocio, indagación y viaje; en definitiva, de inducir al espectador a conocer y revivir los espacios filmados. Se constata incluso en las últimas décadas cómo el territorio utilizado en el cine se convierte en común objeto de visita ${ }^{12}$. La obra cinematográfica genera así un recurso de promoción cultural que divulga la forma, la materia y el significado de los paisajes. Además, si en éstos han sido identificados previamente valores naturales y culturales merecedores de una consideración excepcional por parte de la ciudadanía, de las instituciones y de los agentes económicos y sociales, el cine aporta un valor añadido en la patrimonialización del paisaje.

Este artículo analiza la imagen paisajística de la costa oriental de Asturias, concretamente del concejo de Llanes, filmada por el director, productor y guionista José Luis Garci (Madrid, 1944) en El abuelo (1998), You're the one (2000) e Historia de un beso (2002) ${ }^{13}$, con la dirección artística de Gil Parrondo (Luarca, 1921-Madrid, 2016). Entre los autores que desde 1941, a tra-

11 GÁMIR ORUETA, Agustín y MANUEL VALDÉS, Carlos, "Cine y Geografía...", opus cit., cf. pp. 158, 159, 164, y 166-168; PLASENCIA LOZANO, Pedro, El paisaje de los puentes urbanos..., opus cit., cf. pp. 285-292 y 403408; ARAÚJO VILA, Noelia y FRAIZ BREA, José Antonio, "Las series audiovisuales como herramienta promocional de un destino turístico: el caso de España”, en Investigaciones Europeas de Dirección y Economía de la Empresa, Vol. 19, nº1, Vigo, 2013, pp. 8-15, cf. pp. 8-10.

12 MARTínEZ PUCHE, Antonio, "El cine como soporte didáctico para explicar la evolución del viaje y la actividad turística", en Cuadernos de Turismo, n²2, Murcia, 2008, pp. 145-163, cf. pp. 160-161; RODRÍGUEZ CAMPO, María Lorena y FRAIZ BREA, José Antonio, "Consideraciones estratégicas para la promoción del turismo en Galicia a través del cine", en Revista Galega de Economía, vol. 19, n 2, Santiago de Compostela, 2010, pp. 1-11, cf. pp. 2 y 5 ; ARAÚJO VILA, Noelia y FRAIZ BREA, José Antonio, "Las series audiovisuales como...". Opus cit., cf. pp. 8-10.

13 Nickel Odeon Dos produce las tres películas, participando en la segunda y en la tercera Enrique Cerezo Producciones Cinematográficas y Productora Cinematográfica Veintinueve. vés del cine y la televisión, han contribuido a difundir el conocimiento de Llanes, Garci es uno de los que mayor vinculación ha adquirido con este territorio. Y las obras señaladas han dado lugar, junto a otras diecinueve de variados autores (incluidos largometrajes, cortometrajes y series televisivas), a un proyecto turístico y cultural de iniciativa municipal, denominado "Llanes de Cine", que pone en valor los paisajes de este sector a través de una selección de escenarios de rodaje ${ }^{14}$.

El vínculo de Llanes con la producción cinematográfica se produce en el contexto de un importante reconocimiento científico, institucional y popular debido a una combinación de criterios que comprenden aspectos ambientales, ecológicos, estéticos, arqueológicos, histórico-artísticos y etnográficos. El concejo posee numerosos elementos distinguidos por acciones de protección del patrimonio natural y cultural (Paisajes Protegidos, Monumentos Naturales, ZEPA, ZEC, BIC, Conjuntos Históricos, bienes declarados Patrimonio Mundial por la UNESCO...) en un territorio relativamente reducido: se extiende sobre unos 30 kilómetros en dirección E-0, limitado por el curso del río Cabra, a oriente, y por el pequeño curso del río Guadamía así como por las cabeceras de los ríos Nueva, Arroyo del Collado de la Tabla, Riensena y Acebales, a occidente. Y en dirección N-S apenas se desarrolla sobre 6-8 kilómetros, encerrado por la recortada línea de costa del mar Cantábrico y la imponente alineación calcárea de la sierra del Cuera.

Del territorio llanisco interesa la valoración de la topografía contrastada y de los singulares rasgos geomorfológicos y vegetales ${ }^{15}$, que de un itinerario que invita a descubrir veinticinco localizaciones correspondientes a escenarios de producciones de cine y televisión rodadas desde 1941 hasta 2008 (http://www.llanesdecine.com). Conviene señalar, además, el lugar que ocupa Llanes en los inicios de la producción cinematográfica en Asturias, pudiendo destacar el temprano rodaje de la película documental Llanes 1917 por la productora francesa Pathé Frères. FRANCO TORRE, Christian, "Patrimonio cinematográfico y fotográfico en Asturias", en Boletin de Letras del Real Instituto de Estudios Asturianos, vol. 61, n 169 , Oviedo, 2007, pp. 85-100., cf. p. 92-93.

15 FLOR RODRÍGUEZ, Germán, "Las rasas asturianas: ensayos de correlación y emplazamiento", en Trabajos de Geología, n 13, 1983, pp. 65-81; ROMERO LÓPEZ, Diana, "Tipología de formas kársticas y relaciones morfoestructurales en la marina oriental asturiana”, en Ería, no 7, Oviedo, 1984, pp. 119-133; FROCHO- 
constituyen el marco de numerosas playas e itinerarios aptos para la actividad recreativa y contemplativa. Al mismo tiempo, es muy apreciada la existencia de importantes vestigios prehistóricos y protohistóricos, y de ejemplos destacados de la arquitectura civil y religiosa de épocas diversas, incluidos los vinculados al paso del ramal costero del Camino de Santiago. No se puede olvidar, además, la huella indiana, de los antiguos emigrantes de la España atlántica a tierras de Ultramar, muchos de ellos originarios de estas tierras, que posteriormente han dejado impronta de su éxito en la dotación de equipamientos, infraestructuras y opulentas villas residenciales en sus localidades de origen, muchas diferenciadas por el estilo modernista, ecléctico o regionalista de sus palacetes y por las exóticas especies arbóreas de sus jardines ${ }^{16}$.

Todas estas cualidades explican que este espacio haya sido uno de los destinos turísticos de promoción más temprana en la región asturiana, a la vez que justifican la atención prestada a sus parajes desde las artes cinematográficas en las últimas siete décadas, representando este aspecto sin duda un nuevo impulso a su proceso de patrimonialización ${ }^{17}$.

\section{Aspectos cinematográficos del paisaje de Llanes en la obra de José Luis Garci}

Dado que este trabajo aborda aspectos específicos del entorno geográfico de Llanes, conviene subrayar que, desde el punto de vista del discurso fílmico, la construcción de los espacios enunciativos en que transcurre la acción suele ser fragmentaria, pues la unidad escénica del mundo ficcional se obtiene mediante rodajes en localizaciones que a menudo distan entre sí. Ello atiende a las características físicas y hu-

SO SÁNCHEZ, Manuel y CASTAÑÓN ÁLVAREZ, Juan Carlos, "El medio natural (II): Las unidades básicas", en Historia de Asturias, tomo I, Editorial Prensa Asturiana, Oviedo, 1990, pp. 17-32; RODRÍGUEZ PÉREZ, Carmen, "El medio natural", en Los paisajes del litoral asturiano, Servicio de Publicaciones de la Universidad de Oviedo, Oviedo, en prensa.

16 MORALES SARO, María Cruz, Llanes y América. Cultura, arte y sociedad, Editorial Porrúa, México D.F., 1999, $273 \mathrm{pp}$.

17 RODRÍGUEZ PÉREZ, Carmen y SEVILLA ÁLVAREZ, Juan, "El paisaje patrimonial del litoral oriental de Asturias: Llanes y Ribadedeva", en Los paisajes patrimoniales de España, Ministerio de Agricultura, Alimentación y Medio Ambiente, Madrid, en prensa. manas de los entornos (orografía, vegetación, clima, asentamientos humanos, espacio construido, infraestructuras ${ }^{18} \ldots$ ), para que contribuyan a los sentidos del relato, así como a necesidades específicas de producción que suelen basarse en la optimización de costes y de plazos de ejecución. Es por lo que, en los tres filmes estudiados, la abundancia de localizaciones de rodaje en el concejo de Llanes se conjuga con lugares de otros ámbitos geográficos. Ejemplo de esto son los espacios exteriores urbanizados del ficcional Cerralbos del Sella para Historia de un beso (2002). Se construyen a partir de localizaciones en los enclaves llaniscos de $\mathrm{Pu}$ rón (00:03:21, 00:15:28 y 01:16:45), la plaza de la Capilla de la Magdalena en el monumental Conjunto Histórico de Llanes (00:54:21) y la bolera de Poo (00:24:25 y 00:42:49), testimonio de la inversión de capital indiano en el equipamiento de las localidades de los exitosos emigrantes a Ultramar (véase Cuadro III). Pero se alternan con localizaciones del centro de Asturias como la iglesia de Santa María de Luanco (Gozón) o el palacio de Meres (Siero). Varios de estos lugares se emplearon igualmente para el Cerralbos del Sella de You're the one (2002).

En este sentido, cabe destacar que, en los relatos aquí tratados, los topónimos ficcionales del galdosiano Jerusa (El abuelo) y del garciano Cerralbos del Sella ${ }^{19}$ (You're the one, 2000 e Historia de un beso, 2002) se conjugan con diversos topónimos empíricos, ya sean extranjeros, como Perú, París y el hospital Quinta Covadonga (fundado, precisamente, por emigrantes asturianos en La Habana, Cuba), nacionales como Madrid, o también específicos de Asturias, como Oviedo y su vecino Las Caldas. Se menciona también el mundo extraficcional mediante referencias públicas, que suelen dar-

18 Garci evoca en su cine el creciente tráfico ferroviario que facilita las comunicaciones en una etapa de desarrollo económico, dinamismo sociocultural e incipiente turismo; aunque el director no hace mención expresa de los lugares reales o de las líneas de transporte de viajeros a que corresponden las escenas asociadas al tren. En El abuelo parece tratarse de la estación de Posada de Llanes, integrada hoy en la red de FEVE e históricamente en los Ferrocarriles Económicos.

19 Llendelabarca sí es un topónimo real pero corresponde al entorno de Trevías (Valdés), en la costa occidental, que marcó la niñez del director artístico Gil Parrondo. PALICIO, Marcos, "El decorado para una historia de entonces", en La Nueva España, Oviedo, 21 de enero de 2011, recuperado de http://www.lne.es/asturias/2011/01/21/decorado-historia/1022689.html [consultado el 15/12/2016]. 

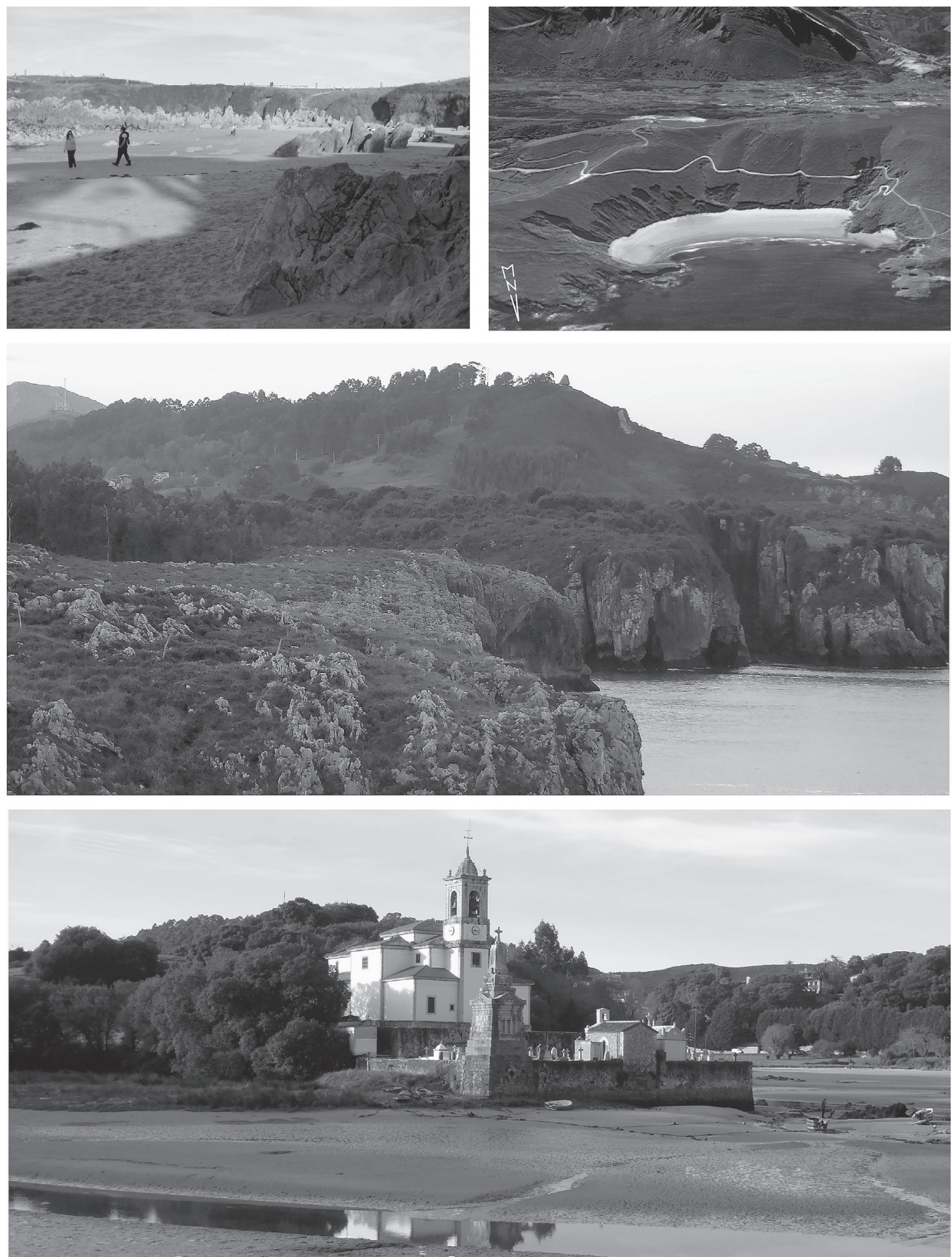

Fig. 2. Localizaciones de la película El Abuelo. Arriba, playas de Toró, a la izquierda (fotografía: Juan Sevilla Álvarez), y Torimbia, a la derecha (imagen de Google Earth de 2014). En el centro, acantilados de Puertas de Vidiago (fotografía: Juan Sevilla Álvarez). Abajo, ría de Barro y cementerio de Niembro (fotografía: Juan Sevilla Álvarez). Salvo en la imagen aérea, los encuadres coinciden aproximadamente con algunos muy representativos del filme. 


\begin{tabular}{|c|c|c|}
\hline $\begin{array}{l}\text { Localizaciones y } \\
\quad \text { escenas }\end{array}$ & Otras películas o series ${ }^{2}$ & Algunos hitos en la patrimonialización \\
\hline \multirow{3}{*}{$\begin{array}{l}\text { Playa de Toró } \\
\text { y acantilado }\end{array}$} & \multirow{6}{*}{$\begin{array}{l}\text {-Aoom (Gonzalo Suárez, } \\
\text { 1970) } \\
\text {-El detective y la muerte } \\
\text { (Gonzalo Suárez, 1994) } \\
\text {-La balsa de piedra } \\
\text { (George Sluizer, 2002) } \\
\text {-Una gloria nacional, } \\
\text { serie (Jaime de } \\
\text { Armiñán, 1993) }\end{array}$} & $\begin{array}{l}\text { - De Llanes a Covadonga. Excursión geográfico-pintoresca }{ }^{3} \text { : "[...] Arcos } \\
\text { que todavía se mantienen de una manera inverosímil, macizas columnatas }\end{array}$ \\
\hline & & $\begin{array}{l}\text { truncadas irregularmente casi a la mitad de su altura...trozos de construcción } \\
\text { que revelan la existencia de notable anfiteatro...todo esto creeréis ver, todo } \\
\text { esto veréis a poco que os dejéis llevar de vuestra fantasía en la playa de Toró }\end{array}$ \\
\hline & & [...]". \\
\hline \multirow[t]{3}{*}{ 01:08:13 - 01:10:22 } & & - Asturias, paraíso del turista": "Sería interminable detallar las playas [...]. La \\
\hline & & de Toro, de bonitas rocas y curiosas rompientes [...]”. \\
\hline & & $\begin{array}{l}\text { - Paisaje Protegido de la Costa Oriental5: “[...] La captura de las dolinas da } \\
\text { lugar a playas como la de Toró o bahías como la de Niembro [...]”. }\end{array}$ \\
\hline Playa de Torimbia & \multirow[b]{2}{*}{$\begin{array}{l}\text {-El Genio tranquilo } \\
\text { (Gonzalo Suárez, 2005) }\end{array}$} & $\begin{array}{l}\text { - Paisaje Protegido de la Costa Oriental (referencia en nota } n^{\circ} 5 \text { ): “[...] Entre } \\
\text { las formaciones geomorfológicas más destacables podemos encontrar: playas }\end{array}$ \\
\hline $\begin{array}{l}01: 07: 16-01: 08: 11 \\
01: 11: 44-01: 13: 17 \\
\left(2^{\text {a }} \text { parte) }\right.\end{array}$ & & $\begin{array}{l}\text { de costa baja, playas de sierra plana, playas en la desembocadura de ríos, } \\
\text { playas de ocupación de dolinas, bufones, tómbolos, castros, dolinas y cuevas, } \\
\text { y sierras planas o rasas, estas de origen marino, antiguas plataformas de } \\
\text { abrasión, que ahora aparecen elevadas sobre el nivel del mar [...]”. }\end{array}$ \\
\hline \multirow{4}{*}{$\begin{array}{l}\text { Acantilados de } \\
\text { Puertas de Vidiago } \\
\text { 00:00:01 - 00:02:12 } \\
\text { (2 parte) } \\
\text { 01:03:44 - 01:05:36 } \\
\text { (2 parte) } \\
\text { 01:05:50 - 01:11:43 } \\
\text { (2 parte) }\end{array}$} & & $\begin{array}{l}\text { - Pequeñas jornadas } 6 \text { : “[...] festoneando la tierra firme el mar en toda su } \\
\text { grandeza }[. . .] " .\end{array}$ \\
\hline & & $\begin{array}{l}\text { - Bellezas de Asturias, de Oriente a } \text { Occidente }^{7} \text { : “...]Después de pasar por el } \\
\text { pueblo de Puertas se camina a través de una meseta de caliza. Y a setenta } \\
\text { metros del mar, se encuentra un pozo al cual se puede bajar con facilidad. } \\
\text { En su centro tiene un agujero que es el extremo acodado de un embudo } \\
\text { subterraneo cuya boca se abre en el tajado cantil [...]". }\end{array}$ \\
\hline & & $\begin{array}{l}\text { - Paisaje Protegido de la Costa Oriental (referencia en nota } n^{\circ 5} \text { ): “[...] el } \\
\text { roquedo calizo ha sufrido procesos de disolución kárstica, dando lugar a un } \\
\text { sinfín de formas de relieve que confieren al área una singular belleza. [...] las } \\
\text { calizas, por otra, han adoptado nuevas formas vinculadas a su capacidad para } \\
\text { disolverse por acción del agua y aparecen formando dolinas, lapiaces, simas, } \\
\text { cuetos, cuevas y otras formaciones, que confieren un aspecto sumamente } \\
\text { atractivo y singular al territorio [...]". }\end{array}$ \\
\hline & & $\begin{array}{l}\text { - Paisaje de Interés Cultural de Asturias }{ }^{8} \text { : F. Referentes geográficos } \\
\text { connotados. F.1. Relacionados con el agua. F.1.3. Litorales." }\end{array}$ \\
\hline \multirow{2}{*}{$\begin{array}{l}\text { Cementerio de } \\
\text { Niembro y ría de } \\
\text { Barro }\end{array}$} & \multirow{4}{*}{$\begin{array}{l}\text {-Epílogo (Gonzalo } \\
\text { Suárez, 1984) } \\
\text {-La Señora, serie (Lluis } \\
\text { María Güell, 2008) }\end{array}$} & $\begin{array}{l}\text { - Historia de Llanes y su concejo }{ }^{9} \text { : “[...] Su posición elevada y sobre la } \\
\text { ensenada, le da un aspecto bellísimo, sobre todo, en los pleamares [...]”. }\end{array}$ \\
\hline & & - Paisaje Protegido de la Costa Oriental (referencia en nota $n^{\circ 5}$ ): “[...] La \\
\hline \multirow{2}{*}{$\begin{array}{l}01: 13: 36-01: 14: 19 \\
00: 58: 55-01: 00: 28 \\
\left(2^{\text {a }} \text { parte) }\right.\end{array}$} & & Niembro [...]" \\
\hline & & $\begin{array}{l}\text { - Paisaje de Interés Cultural de Asturias (referencia en nota n 8): "E. Sistemas } \\
\text { de creencias, artes y comunicación. E.1. Ritual. E.1.2. Culto y rito funerario". }\end{array}$ \\
\hline \multirow{2}{*}{$\begin{array}{l}\text { Estación de Posada } \\
\text { de Llanes } \\
\text { 01:02:58 - 01:03:43 } \\
\text { (2a parte) } \\
01: 05: 37-01: 05: 49 \\
\text { (2a parte) }\end{array}$} & \multirow{2}{*}{$\begin{array}{l}\text {-Epilogo (Gonzalo } \\
\text { Suárez, 1984) } \\
\text {-Historia de un beso } \\
\text { (José Luis Garci, 2002) }\end{array}$} & $\begin{array}{l}\text { - Guia General de Asturias para } 1905^{10} \text { : “[...] atraviesa el concejo la carretera } \\
\text { de Torrelavega a Oviedo con coches de linea hasta Arriondas a enlazar con el } \\
\text { FFCC de Oviedo a Santander cuyas obras (del tramo) de Arriondas a Llanes estàn } \\
\text { muy adelantadas [...]". }\end{array}$ \\
\hline & & $\begin{array}{l}\text { - Asturias, paraíso del turista (referencia en nota } n^{\circ} 4 \text { ): "[...]La animación de } \\
\text { la vida maritima fue sustituida por la que el FFCC trae a diario a la capital del } \\
\text { Oriente astur. Término de los Economicos y del Cantábrico, numerosos trenes la } \\
\text { cruzan a diario [...]". }\end{array}$ \\
\hline
\end{tabular}

Se utiliza la versión emitida en TVE en dos capítulos

La indicación de otras películas o series, en los Cuadros I a III, se basa en la web del proyecto "Llanes de Cine".

FORONDA, Manuel de, De Llanes a Covadonga, con prólogo de Ignacio Quintana, Temas Llanes n 63, Llanes, 1993, 218 pp., cf. pp. 7- 14.

4 PÉREZ Y PIMENTEL, Antonio, Asturias, paraiso del turista, Talleres Tipográficos Editorial Covadonga, Gijón, 1925, 252 pp., cf. pp. 22 y $82-83$.

5 PRINCIPADO DE ASTURIAS, Paisaje Protegido de la Costa Oriental, recuperado de http://www.asturias.es/medioambiente/articulos/ficheros/Paisaje\%20Protegido\%20de $\% 201 \mathrm{a} \% 20$ Costa\%20 Oriental_noPW.pdf [consultado el 05/11/2016]

$6 \quad$ SARO Y ROJAS, José, Pequeñas Jornadas, Temas Llanes, n²8, El Oriente de Asturias, Llanes, 1985, 111 pp., cf. p. 20.
$7 \quad$ LLANO ROZA DE AMPUDIA, Aurelio del, Bellezas de Asturias, de Oriente a Occidente, Diputación Provincial, Imprenta Gutenberg, Oviedo, 1928, 542 pp., cf. pp. 8-9.

8 FERNÁNDEZ SALINAS, Víctor, "Los paisajes de interés cultural de Asturias", en Ería. Revista Cuatrimestral de Geografía, nº91, Oviedo, 2013, pp. 129-149, cf. 143-145.

9 CANELLA SECADES, Fermín, Historia de Llanes y su concejo, Establecimiento Tipográfico de Ángel de Vega, Llanes, 1896, 488 pp., cf. p. 204.

10 GUTIÉRREZ MAYO, JosÉ y ÁLVAREZ URÍA, Gerardo, Guía General de Asturias para 1905, Compañía Asturiana de Artes Graficas, Gijón, 1905, 422 pp., cf. p. 212. 
se en las tertulias del Bar España de Cerralbos del Sella: las proyecciones cinematográficas de Hollywood y sus correspondientes comentarios por parte de los personajes de You're the one (destaca el enfrentamiento entre Tía Gala y Don Matías), el interés de Blas Otamendi y Don Telmo por la rivalidad futbolística entre el Sporting de Gijón y el Oviedo; e incluso se plasma fílmicamente la línea Oviedo-Luarca-Vegadeo (nótese que recorre la costa occidental, geográficamente opuesta a la de Llanes), operada desde principios del siglo XX por la histórica empresa asturiana de autobuses "El Luarca" (ALSA) y cuyas paradas conectan dichos lugares empíricos con el ficcional Cerralbos del Sella.

Tal fenómeno combinatorio entre nuestros referentes empíricos y los mundos ficcionales de estas películas aporta gran riqueza semántica por estar muy ligado a una dominante temática que, abundante en la tradición trágica occidental, también está presente en $\mathrm{El}$ abuelo, You're the one e Historia de un beso. Nos referimos a las concepciones del mundo como representación y la correspondiente disolución fronteriza entre la realidad y la ficción, entre el presente empírico y el pasado onírico, tan presentes en las señeras obras de Calderón de la Barca y de Shakespeare de las que se hacen eco los ancianos amigos de El abuelo (2a parte, 01:12:20).

En sólida consonancia con dicha herencia de las cosmovisiones trágicas, en las películas estudiadas existen diversos elementos simbólicos escénicos que son recurrentes en las artes y para los cuales ofrece muy interesantes entornos el litoral de Llanes: la playa como espacio fronterizo entre lo conocido y lo inescrutable, el abismo (aquí en forma de acantilado) para significar una situación existencial limitrofe, el río como símbolo del transcurso vital (con adyacentes como los caminos que los recorren y los puentes que los cruzan).

Así pues, en términos comunicativos artísticos en general y de relato en particular, las localizaciones geográficas de toda obra audiovisual se seleccionan según tales funcionamientos simbólicos que adquirirán en la historia, requisito estético que cumplen con poética solvencia los tres filmes que nos ocupan. Con independencia de que su director presente cier- to interés personal por filmarlos en Asturias ${ }^{20}$, en ellos se evidencian diversos temas y conflictos subjetivos de los personajes para los que la geografía de Llanes ofrece parajes de muy eficaz valor discursivo.

Sin pretender aquí enumerar cuantos aspectos geográfico-estéticos puedan conjugarse en los relatos seleccionados ni agotar (suponiendo que fuera posible) las relaciones entre sus diversos elementos simbólicos, presentamos a continuación un análisis de los enclaves llaniscos empleados en El abuelo, You're the one e Historia de un beso en los que Garci establece a nuestro entender determinados usos simbólicos principales que conectan con arraigadas tradiciones estéticas occidentales, centrándonos particularmente en los tres elementos antedichos (playas, acantilados y entornos fluviales) y en escenarios vinculados a los anteriores, incluidos algunos elementos antrópicos de nuestro ámbito geográfico de estudio. Se ha considerado de especial interés poner en relación el modo en que el cineasta recurre a estos espacios con los valores naturales y culturales que los singularizan. De ahí que, a la identificación de los lugares concretos, efectuada en un primer visionado de los tres filmes -con el apoyo de la información que ofrece "Llanes de Cine"-, haya seguido un estudio del proceso histórico de patrimonialización de la costa llanisca con el fin de seleccionar hitos en la difusión del conocimiento, valorización y/o protección de los mismos lugares (a partir de trabajos de viajeros, cronistas, literatos, científicos, agentes sociales e instituciones oficiales, fundamentalmente). De este modo, el posterior análisis pormenorizado de El abuelo, You're the one e Historia de un beso ha podido

\footnotetext{
El vínculo de José Luis Garci con Asturias tiene que ver con la procedencia de su padre y las estancias vacacionales disfrutadas con su familia durante la infancia. El reencuentro con los paisajes vividos le llevarian a rodar Volver a empezar en la región y posteriormente otras siete obras, entre las que se encuentran las aquí analizadas. La experiencia personal también influye en la magistral dirección artística de Gil Parrondo, natural de Valdés. OLLERO LÓPEZ, Daniel Jerónimo, “Entrevista con José Luis Garci", en Red Cinéfila, 20 de mayo de 2009, recuperado de http://redcinefila.blogspot. com.es/2009/05/entrevista-con-jose-luis-garci.html [consultado el 30/10/2016]; MARTÍNEZ EXPÓSITO, Alfredo, "La estetica del lugar en El Abuelo (Galdos/ Garci) y la fortuna cinematografica de la novela realista-naturalista española”, en Au Naturel: (Re)Reading Hispanic Naturalism, Cambridge Scholars Publishing, Newcastle, 2010, pp. 277-298.
} 
verificar si los valores y las cualidades históricamente reconocidos en los espacios elegidos para el rodaje adquieren importancia en el relato, participando del mensaje garciano, y de este modo las tres obras de Garci contribuyen a la patrimonialización del paisaje.

Por su esencia fronteriza entre la tierra firme y el mar, acentuada en Llanes debido al perfil recortado del acantilado en el que se insertan, a las formas caóticas derivadas de la acusada disolución kárstica y a los truncados afloramientos que las salpican, las playas son a menudo escenarios de situaciones donde se confronta el statu quo habitual del personaje protagonista de la escena con una trascendencia inquietante o inescrutable, por ejemplo espiritual, cultural, social o familiar; de ahí que en cualquier forma de relato (literario, escénico, pictórico, fotográfico, audiovisual...), sea habitual situar la acción en un espacio "playa" que revista simbólicamente a los sujetos con dichas ideas de incertidumbre.

De manera específica, se observa en las tres obras de Garci que las playas son enclaves de encuentro intimo. En You're the one, la playa del ficcional de Cerralbos del Sella (filmada en Cuevas de Mar) enmarca una inquietante escena donde el graznido de las gaviotas se sustituye por el de unos cuervos, acaso para realzar el carácter oracular de la Tía Gala mientras, acariciada por la brisa y en soledad frente a los dos rugosos y horadados cantiles que abrazan la playa, con la mar penetrando suavemente en el abrigo natural, observa el infinito (00:22:30). El mismo escenario, jalonado de cavidades formadas en la caliza, con siluetas irregulares y caprichosas, algunas con aspecto de disformes arcos ojivales (como observara Guy Mary, véase Cuadro II), contempla el encuentro de la atormentada Julia con sus recuerdos y con su incierto porvenir (00:27:56), notablemente acentuado por el peculiar reflejo de la arena que ofrecen las mareas bajas del litoral cantábrico. En esta playa, profunda desde el frente costero en bajamar, el efecto mencionado adquiere asombrosa belleza. Si el sacerdote Don Matías expresa su conflicto existencial tras asearse ante el espejo (01:24:45), el de Julia se subraya con su reflejo en la extensa superficie de arena húmeda mientras ella contempla la inmensidad insondable del océano en que se ha convertido su vida. Por tanto, la elección de una playa con un contraste paisajístico muy llamativo entre pleamar y bajamar, óptimo para el registro de la paulatina retirada del Cantábrico, constituyó una necesidad del rodaje que Cuevas de Mar pudo satisfacer ${ }^{21}$.

Asimismo, las playas de las obras estudiadas funcionan como entornos para los encuentros generacionales, también íntimos (los públicos se establecen en lugares más concurridos, como el bar o la iglesia).

En El abuelo, Don Rodrigo de Albrit entabla diálogo con sus nietas en una escena de gran importancia simbólica para el relato y rodada en la playa de Toró. Les explica el anciano que su carácter áspero se ve acentuado por la actitud desagradecida que le demuestran quienes habían estado a su servicio, pero también bajo su amparo, durante décadas (01:08:12). En la elección de este paraje para filmar la escena influyó quizá el hecho de que sus numerosas y peculiares rocas, asemejando pináculos y pilares truncados, evoquen los restos de arquitecturas otrora majestuosas como señalara Foronda en 1884 a la Sociedad Geográfica de Madrid (véase Cuadro I), lo cual establece un interesante correlato hacia el conflicto principal del anciano: el derrumbe de su noble estirpe y el problema de que una nieta ilegítima pueda deshonrar el apellido Albrit.

En You're the one la playa (Cuevas de Mar) presencia la evolución psicológica de Julia. Primero, la hermosa y atormentada viuda conversa con la Tía Gala sobre el recuerdo del esposo difunto (00:45:12), afirmando la más veterana que el alma de él se manifiesta en múltiples gestos de la naturaleza: "Él también piensa en usted. A veces, hasta dice su nombre. Usted lo escucha, pero se engaña diciéndose que no es él, sino el río, el viento o la rama que rasca en lo cristales... Cualquier cosa" (00:46:49). En ese momento el agua amaga acercarse hasta el lugar en que permanecen las dos mujeres; pequeñas olas acarician la orilla. Más tarde (01:24:17), la protagonista y Juanito vuelan la vieja cometa con forma de barco velero que la Tía Gala había reparado (nótese el simbolismo de "barco que vuela más niño" para ilustrar el proceso curativo del alma). Finalmente, cuando ella regresa a Madrid tras haber iniciado el alivio de su corazón, Juanito y el maestro, Orfeo, se confiesan el amor que am-

\footnotetext{
21 Este escenario enriquece la estética de Garci y Gil Parrondo merced a la variedad de texturas de la plataforma costera y de la línea de costa: la aspereza del matorral y, aún mayor, de la superficie calcárea que éste recubre, la rugosidad también perceptible en el pedrerío descubierto por la bajamar, la suavidad de pradería, la finura de la arena...
} 


\begin{tabular}{|c|c|c|}
\hline $\begin{array}{l}\text { Localizaciones } \\
\text { (escenas) }^{1}\end{array}$ & $\begin{array}{l}\text { Otras películas } \\
\quad \text { o series }\end{array}$ & Algunos hitos en la patrimonialización \\
\hline & & $\begin{array}{l}\text {-Asturias, paraíso del turista (referencia en nota }{ }^{\circ} 4 \text { del cuadro I): “[...] } \\
\text { Dejando a la izquierda Cuevas del Mar, de bonitas grutas y concurrida } \\
\text { playa [...]”. }\end{array}$ \\
\hline $\begin{array}{l}\text { Playa de Cuevas del } \\
\text { Mar } \\
\text { 00:22:30 - 00:22:51 } \\
00: 27: 56-00: 28: 56\end{array}$ & & $\begin{array}{l}\text {-Évolution de la bordure côtière asturienne (Espagne) du Neogène à } \\
\text { l'actuel }^{2}: \text { “...] La paroi occidentale montre neuf gisements de galets } \\
\text { de grès cimentés par du travertin associés à des cavités karstiques } \\
\text { aménagées par la mer. La paroi orientale [...] Elle est percée de trois } \\
\text { ouvertures ogivales donnant à l'ensemble l'allure d'un pont inachevé } \\
\text { [...]”. }\end{array}$ \\
\hline $\begin{array}{l}01: 24: 17-01: 24: 24 \\
01: 43: 30-01: 45: 22\end{array}$ & & $\begin{array}{l}\text {-Paisaje Protegido de la Costa Oriental (referencia en nota } n^{\circ} 5 \text { del } \\
\text { cuadro I): "las calizas, por otra, han adoptado nuevas formas vinculadas } \\
\text { a su capacidad para disolverse por acción del agua y aparecen formando } \\
\text { dolinas, lapiaces, simas, cuetos, cuevas y otras formaciones, que } \\
\text { confieren un aspecto sumamente atractivo y singular al territorio [...]". }\end{array}$ \\
\hline \multirow{3}{*}{$\begin{array}{l}\text { Paseo del río Purón } \\
\text { 00:29:10 - 00:29:45 } \\
00: 42: 36-00: 43: 49 \\
01: 24: 30-01: 24: 38\end{array}$} & & $\begin{array}{l}\text {-Paisaje Protegido de la Sierra del Cuera3: “[...] La sierra del Cuera } \\
\text { constituye sin duda el elemento que en mayor medida contribuye a } \\
\text { definir el paisaje y organizar el espacio del extremo oriental de Asturias. } \\
\text { Se trata de una barrera montañosa situada a apenas seis kilómetros de } \\
\text { la costa, lo que reduce sustancialmente las rasas costeras y limita el } \\
\text { poblamiento del litoral [...]". }\end{array}$ \\
\hline & & $\begin{array}{l}\text {-Paisaje de Interés Cultural de Asturias (referencia en nota n }{ }^{\circ} 8 \text { del } \\
\text { cuadro I): "D. Sistemas de producción y transformación. D.1. Agrario y } \\
\text { pesquero. D.1.1. Usos agroganaderos no especializados". }\end{array}$ \\
\hline & & $\begin{array}{l}\text {-Zona Especial Conservación Río Purón }{ }^{4} \text { : [...] Pequeño río costero con } \\
\text { presencia de salmón y nutria [...]. Vegetación de ribera bien conservada" }\end{array}$ \\
\hline $\begin{array}{l}\text { Pueblo de Purón } \\
01: 23: 12-01: 23: 21\end{array}$ & $\begin{array}{l}\text {-Historia de un beso (José } \\
\text { Luis Garci, 2002) }\end{array}$ & $\begin{array}{l}\text {-Paisaje de Interés Cultural de Asturias (referencia en nota no } 8 \text { del } \\
\text { cuadro I): "D. Sistemas de producción y transformación. D.1. Agrario y } \\
\text { pesquero. D.1.1. Usos agroganaderos no especializados". }\end{array}$ \\
\hline
\end{tabular}

1 Identificación de localizaciones y producciones de cine y televisión según el proyecto "Llanes de Cine". Podría añadirse la localización de un merendero junto a la playa de Toró, en una escena de pleamar con tiempo fresco y ventoso (01:23:50) que vendría a representar el uso recreativo desestacionalizado del borde de mar en el litoral cantábrico.

2 MARY, Guy, Évolution de la bordure côtière asturienne (Espagne) du Neogène à l'actuel, Thèse de Doctorat d'État (inédita), Universidad de Caën, 1979, 3 vols., cf. p. 210.

3 PRINCIPADO DE ASTURIAS, Paisaje Protegido de la Sierra del Cuera, recuperado de http://www.asturias.es/medioambiente/articulos/ficheros/Plantilla\%20Paisaje\%20Protegido\%20
de\%20la\%20Sierra\%20del\%20Cuera_noPW.pdf [consultado el 05/11/2016].

4 UNIÓN EUROPEA, Natura 2000-Standard Data Form ES 1200034Río Purón, recuperado de https://www.asturias.es/ portal/site/medioambiente/menuitem.1340904a2df84e62fe$47421 \mathrm{ca} 6108 \mathrm{a0c} /$ ?vgnextoid=88c3c059c5a73210VgnVCM100 00097030a0aRCRDEtvgnextchannel=fcd25b51 cb90c110VgnVCM1000006a01a8c0RCRDCti18n.http.lang=es [consultado el 05/11/2016].

5 El pueblo de Purón se identifica con esta película en www.asiyeasturies.com y ha sido asimismo identificado por los autores del presente artículo. 

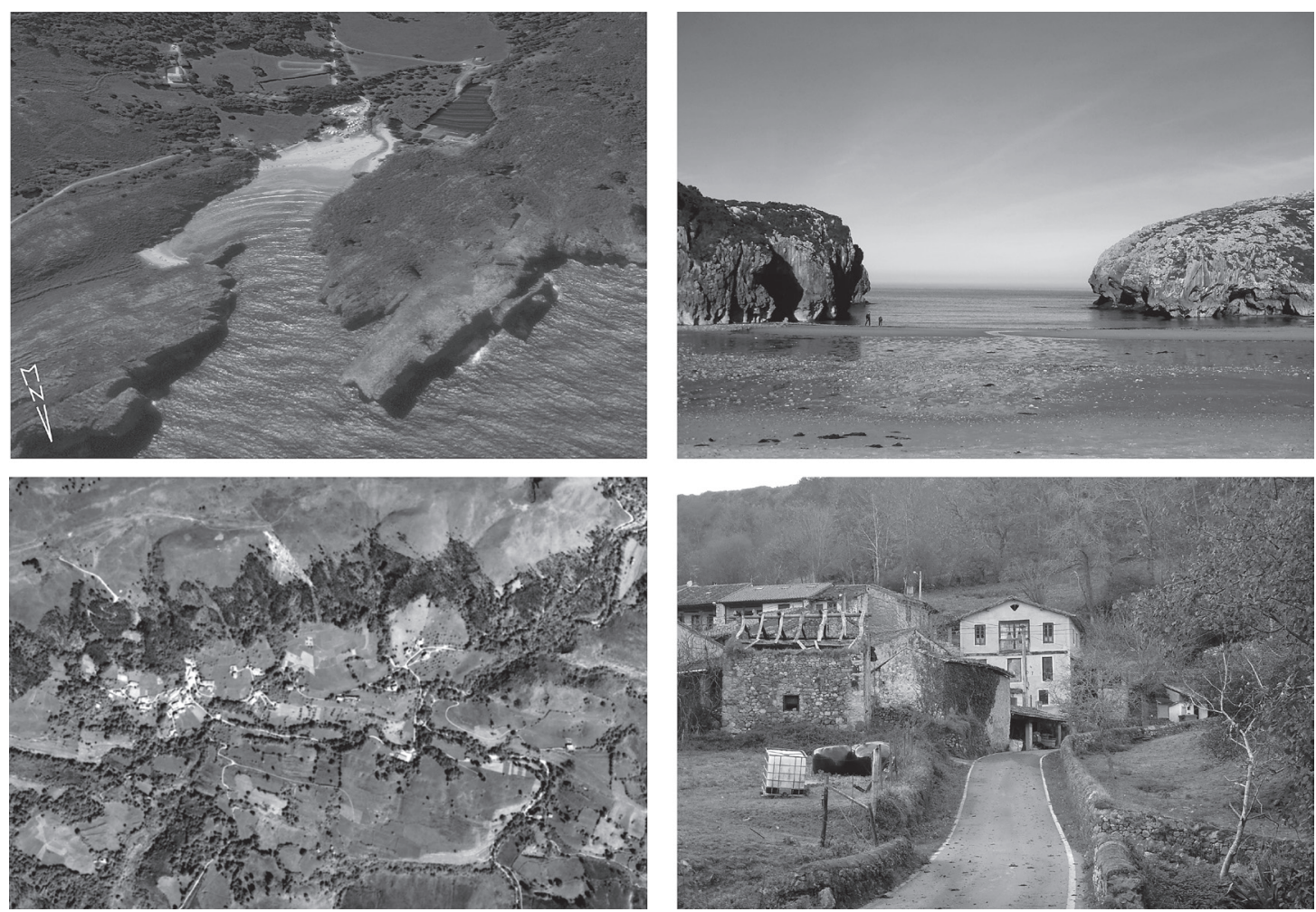

Fig. 3. Localizaciones de la película You are the one. Arriba, vista general (imagen de Google Earth de 2014) y de detalle (fotografía: Juan Sevilla Álvarez) de la playa de Cuevas de Mar. Abajo, vista general (Vuelo del Principado de Asturias, fragmento del fotograma 2123) y de detalle (fotografía: Juan Sevilla Álvarez) del pueblo de Purón en el valle del río homónimo. Las dos imágenes de la derecha presentan encuadres equivalentes a los tomados por el equipo de Garci.

bos sienten por Julia. Es interesante destacar que el niño, como el anciano conde de El abuelo, se halla sentado en una roca de la playa (01:43:34), lo cual simboliza el deseo de que lo conocido permanezca. Pero el maestro Orfeo (adviértase la referencia mitológica griega) lo anima a volar de nuevo la cometa-barco para que siga viviendo libre. En consonancia con la dualidad blanco-negro que articula el relato (incluso en su soporte fotográfico), la historia concluye al alegre son musical extradiegético ${ }^{22}$ del Night and day de Cole Porter (1932).

En cuanto a Historia de un beso, la playa de Barro acogió las escenas retrospectivas donde Julipín, primero, se enamora y es correspondido por la niña Beatriz (00:34:57) y, un año después, comprende que ella prefiere distanciarse de él (todavía muy niño), a favor de un apuesto adolescente (01:17:10). Estos mismos pasajes

22 Se entiende por música extradiegética aquella que se manifiesta de forma superpuesta al mundo ficcional representado o diégesis, siendo intradiegética la originada dentro de dicho universo, como la mana del gramófono de Julia. merecen un posterior comentario sobre la naturaleza pictórica de sus concepciones.

Cabe mencionar que los encuentros intergeneracionales más notables se filmaron esta vez en el balneario y el casino de Las Caldas, en el concejo de Oviedo (aquí se hace explícito el funcionamiento simbólico del agua como elemento purificador), siendo, no obstante, el Paseo de San Pedro, en la villa de Llanes (00:47:18), el marco para que Julipín y Don Blas intercambiasen pareceres sobre el amor. Allí, enmarcando el encuentro, en un espacio decimonónico concebido para la relación social, la contemplación y el ocio, aparece un guiño a la Asturias tradicional con la representación del juego de bolos, de notable valor etnográfico (00:49:13). Este enclave ofrece, por lo demás, similares valores simbólicos relativos a lo limitrofe: el paseo, de trazado casi rectilíneo, se extiende paralelo al mar junto al borde septentrional de la villa. Regala una vista panorámica de todo el litoral, dominada por la majestuosa oposición de mar abierto y barrera montañosa erguida sobre la quebrada peana de la plataforma costera. Son impresiones ya sub- 


\begin{tabular}{|c|c|c|}
\hline $\begin{array}{l}\text { Localizaciones } \\
\text { (escenas) }\end{array}$ & $\begin{array}{l}\text { Otras películas } \\
\quad \text { o series }\end{array}$ & Algunos hitos en la patrimonialización \\
\hline $\begin{array}{l}\text { Playa de Barro } \\
\begin{array}{l}00: 34: 57-00: 36: 10 \\
01: 17: 10-01: 17: 54\end{array}\end{array}$ & $\begin{array}{l}\text {-El portero (Gonzalo } \\
\text { Suárez, 2000) } \\
\text {-La Señora, serie (Lluis } \\
\text { María Güell, 2008) }\end{array}$ & $\begin{array}{l}\text {-Guía General del Viajero en Asturias }{ }^{1} \text { : "Llanes [...] tiene, entre otras, } \\
\text { las cómodas playas del Sablón y Sablín...No son muy frecuentadas, y } \\
\text { debieran serlo, las playas de Celorio y Barro. [...]" } \\
\text {-Paisaje Protegido de la Costa Oriental (referencia en nota no } 5 \text { del } \\
\text { cuadro I; véase misma cita reseñada para Cuevas del Mar) }\end{array}$ \\
\hline $\begin{array}{l}\text { Paseo de San Pedro } \\
\text { de Llanes } \\
\text { 00:47:18 - 00:49:28 }\end{array}$ & & $\begin{array}{l}\text {-De Llanes a Covadonga. Excursión geográfico-pintoresca (referencia } \\
\text { en nota } n^{\circ} 3 \text { del cuadro I): "[...]lo grandioso del espectáculo que la } \\
\text { naturaleza nos ofrece, recompensa sobradamente lo largo del viaje [...]. } \\
\text { Observad al 0. la cadena de montañas que interponen sus elevadas } \\
\text { cumbres entre nosotros y las famosas cimas de Covadonga [...]". } \\
\text {-Bellezas de Asturias, de Oriente a Occidente }{ }^{2} \text { : “[...]...trazado a lo largo } \\
\text { del abrupto cantil, donde la naturaleza nos ofrece un cuadro grandioso } \\
\text { [...]. Paralelamente al mar se yergue la sierra del Cuera envuelta en } \\
\text { un velo de niebla luminosa; y se extiende el valle risueño, entre cuya } \\
\text { arbolada se ven casitas blancas y elegantes hoteles que alquilan los } \\
\text { forasteros que vienen a veranear a este delicioso pais. Y abajo, al pie } \\
\text { del paseo, la villa señoril [...]". }\end{array}$ \\
\hline
\end{tabular}

Pueblo de Purón

00:03:21 - 00:03:34

$00: 15: 28-00: 16: 08$

01:16:45- 01:17:09
-You're the one (José Luis Garci, 2000)
-Paisaje de Interés Cultural de Asturias (referencia en nota $\mathrm{n}^{0} 8$ de cuadro I): "D. Sistemas de producción y transformación. D.1. Agrario y pesquero. D.1.1. Usos agroganaderos no especializados".
Plaza de la Capilla de la Magdalena (Llanes)

$00: 54: 21-00: 54: 35$
-Conjunto Histórico de Llanes 3 : "[...] las capillas de San Roque y de la Magdalena, y otros muchos edificios de destacada valía que prestan singular fisonomía a la villa de Llanes [...]".

-Paisaje de Interés Cultural de Asturias (referencia en nota ${ }^{\circ} 8$ del cuadro I): "A. Sistema de asentamiento. A.2. Dominante urbana. A.2.2. Ciudades y villas de tradición medieval y moderna".

\section{Bolera de Poo}

$00: 24: 25-00: 24: 29$

00:42:49 - 00:43:09
-Historia de Llanes y su concejo (referencia en nota $n^{\circ} 9$ del cuadro I): "[...] Hoy es un pueblo floreciente, con elegante templo, excelente cementerio y obras que acreditan el amor de sus naturales [...]".

-Ruta Indiana4: “[...] También se construyó con capital indiano la iglesia, el cementerio, la bolera y el casino" [...].
1 BELLMUNT, Octavio y CANELLA, Fermín, Guía General del Viajero en Asturias, Fototipia y Tipografía de Octavio Bellmunt y Cia., Gijón, 1899, 162 pp., cf. p. 18.

2 LLANO ROZA DE AMPUDIA, Aurelio del, Bellezas de..., opus cit., cf. pp. 14-16.

3 GOBIERNO DE ESPAÑA, "Decreto 1021/1971, de 22 de abril, por el que se declara Conjunto Histórico-Artístico la villa de
Llanes (Asturias), en Boletín Oficial del Estado, Núm, 112, Madrid, 11 de mayo de 1971, pp. 7.555-7.556.

4 AYUNTAMIENTO DE LLANES, Ruta indiana, recuperado de http://www.llanes.com/sites/default/files/RUTA\%20INDIANA_0.pdf [consultado el 05/11/2016]. 

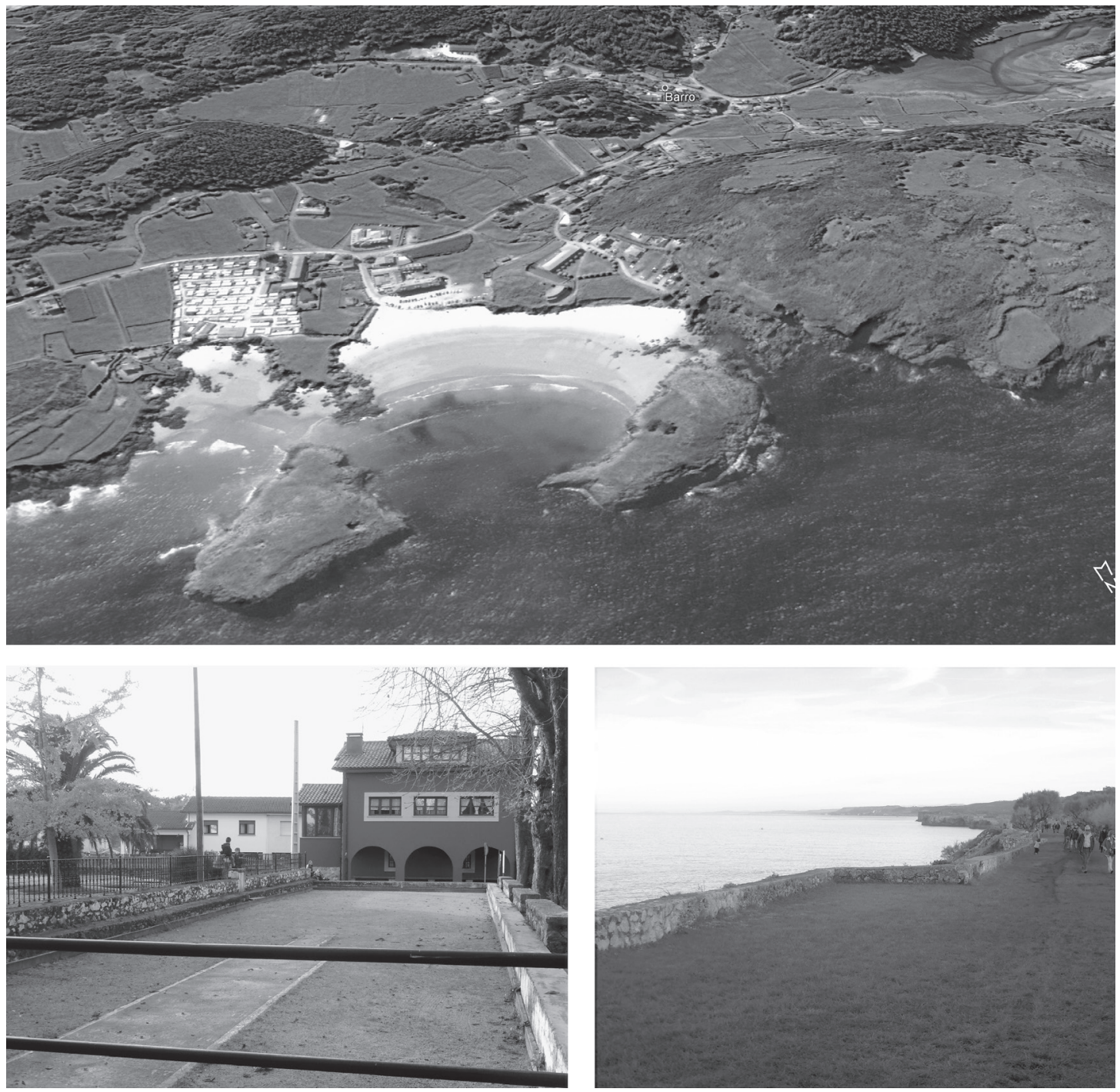

Fig. 4. Localizaciones de la película Historia de un beso. Arriba, playa de Barro (imagen de Google Earth de 2014). Abajo, a la izquierda, la bolera de Poo (fotografía: Juan Sevilla Álvarez), y a la derecha, paseo de San Pedro en la villa de Llanes (fotografía: Juan Sevilla Álvarez). Las fotografías de Poo y Llanes presentan encuadres muy similares a los elegidos por el cineasta.

rayadas siglos atrás en la crónica del primer viaje del emperador Carlos a España, por Laurent $\mathrm{Vital}^{23}$; las mismas que vienen a motivar, después de un dilatado reconocimiento científico e intelectual, la declaración de dos Paisajes Protegidos (Sierra del Cuera y Costa Oriental) en el Plan de Ordenación de Recursos Naturales de Asturias (véanse, en general, Cuadros I a III).

Por otra parte, los encuentros entre jóvenes y adultos conectan muy directamente con una clave temática dominante en las tres películas

$23 \quad$ Vital, L., Relación del primer viaje de Carlos V a España por el cronista Lorenzo Vital (capitulos XXXII-XL). Instituto de Estudios Asturianos, Oviedo,1958, 31 pp. y bien inserta en las cosmovisiones trágicas de la existencia: el ineludible sometimiento de los sujetos al paso del tiempo, cuya naturaleza inexorable y cíclica, abrumadora para el ser humano, parece no afectar al entorno natural. Don Rodrigo de Albrit lo sabe concretar con exquisitez lírica para que sus nietas lo comprendan (00:19:55).

En estrecha relación con las playas por ser también fronterizos entre la tierra firme y el mar, los acantilados presentan la característica añadida de permitir que el sujeto observe el mundo desde la altura. El horizonte resulta más distante, el mar resulta más inmenso... pero, sobre todo, un acantilado permite simbolizar 
las complejas situaciones vitales límite que experimentan los personajes porque, literalmente (visualmente), son ubicados "ante un abismo". Ello explica el uso frecuente de este accidente geográfico en la historia de El abuelo pues los universos respectivos de Pío Coronado y del Conde de Albrit están al borde de la desaparición. De ahí que el anciano y arruinado abuelo, actor de una esplendorosa época extinta (no se olvide el espíritu noventayochista de la novela galdosiana), decida finalmente acompañar al indeciso maestro en su determinación suicida.

Para esta película se aprovecharon los cantiles más occidentales de Torimbia (01:07:36), en la base de una de las sierras planas cuarcíticas que alcanzan la costa, al oeste de Posada. Desde una posición dominante observa Don Rodrigo el juego de sus nietas y el león que, dibujado en la arena, quedará borrado por una fuerza superior tan pronto como la estirpe Albrit de la que es emblema. En cuanto a los acantilados de Puertas de Vidiago, por debajo del nivel de las sierras planas ${ }^{24}$, fueron testigos de los respectivos pasajes en que el maestro Pío Coronado no encuentra valor para suicidarse solo (2a parte, 00:00:01) y donde ambos ancianos deciden saltar para terminar sus vidas, ya sin sentido, de una vez por todas (2a parte, 01:03:44 y 01:05:50). La morfología kárstica de este nivel de rasa asiste bien al sentido de las escenas, con su muesca en la base del acantilado, de perfil festoneado, y la sacudida rítmica del mar; siendo aristosa y agreste la superficie culminante por la formación del lapiaz. Es el mismo lugar que, fijándose en los impactantes bufones (hoy declarados Monumento Natural), ensalza el poeta romántico José Zorrilla en su Cantar del Romero $^{25}$ y divulga la crónica local o algunos de los primeros autores de guías monográficas de Asturias a finales del siglo XIX y comienzos del XX (véase Cuadro I). Precisamente, por allí discurre el ramal costero del Camino de Santiago, incluido en la lista del Patrimonio Mundial por la UNESCO en $2015^{26}$ (aunque el crucero de las escenas no se encuentra en tal lugar).

24 Se aprecia en segundo término la de Cué, más allá de la desembocadura del Purón (2a parte, 00:00:45).

25 AA.VV., Asturias vista por viajeros románticos extranjeros $y$ otros visitantes $y$ cronistas famosos. Siglos $X V$ al $X X$. Introducción, selección y notas de José Antonio Mases, Ediciones Trea, Gijón, 2001, 1.359 pp., cf. p. 300.

26 UNESCO, 39a reunión del Comité del Patrimonio Mundial, recuperado de http://es.unesco.org/39whe [consultado el 19/12/2016].
Luego, al fondo, más allá de prados irregulares y cuetos o resaltes rocosos, se divisa en algunos momentos la silueta de una tercera unidad de relieve encerrando la acción; es la sierra del Cuera, verdadera pantalla de más de 1.300 metros de altitud (2a parte, 00:01:12 y 01:08:34). Si la verticalidad de la sierra, igualmente esculpida en materiales calcáreos, marca en instantes concretos la escena, la atmósfera de tonalidades grisáceas tan habitual en las regiones cantábricas y característica de este litoral, adquiere el mismo protagonismo. Tiene que ver con la condensación y saturación del vapor de agua de las masas de aire húmedo ante este relieve abrupto tan próximo al mar. Garci capta el fenómeno a la perfección y lo integra a menudo en su lenguaje, al igual que el impresionista Darío de Regoyos al pintar desde San Pedro Murallas de Llanes (1909).

Conocido suele resultar asimismo que el curso de un río se utiliza desde antiguo como metáfora lírica que simboliza el recorrido vital del sujeto. En las tres películas tratadas existen situaciones de íntima conversación donde los personajes pasean por caminos al abrigo de la vegetación de ribera y se evidencian los cantos de aves diversas. Pero es en You're the one donde los recoletos ríos asturianos adquieren más protagonismo, asociados a la actividad recreativa propia de los espacios ribereños. En efecto, por el paseo fluvial del río Purón (Zona Especial de Conservación según la Unión Europea, véase Cuadro II) regresan de la escuela Juanito y su amigo, hablando sobre Julia y emplazándose para pescar más tarde (00:29:08). En el mismo enclave pescará después la protagonista, primero en compañia de Juanito (00:42:36) y sola en los últimos compases del relato (01:24:30). Se trata de escenas donde el símbolo vital del "río que fluye" se conjuga con la evolución del vestuario de Julia, desde el negro hacia el blanco, para significar la progresión del personaje desde su inicial estado depresivo hacia la incipiente alegría del ánimo.

Por su parte, en El abuelo, las visitas de Don Rodrigo a su difunta esposa se producen en el cementerio de Niembro (01:13:36; $2^{\text {a }}$ parte, 00:58:55). Es un marco geográfico solemne por el emplazamiento del espacio funerario sobre la ría de Barro, aspecto que motiva su propuesta como Paisaje de Interés Cultural de Asturias en tanto que referente de lugares connotados por sistemas de creencias, artes y comunicación (véase Cuadro I). El lugar, encuentro zigzagueante del Cantábrico con el curso del Ca- 

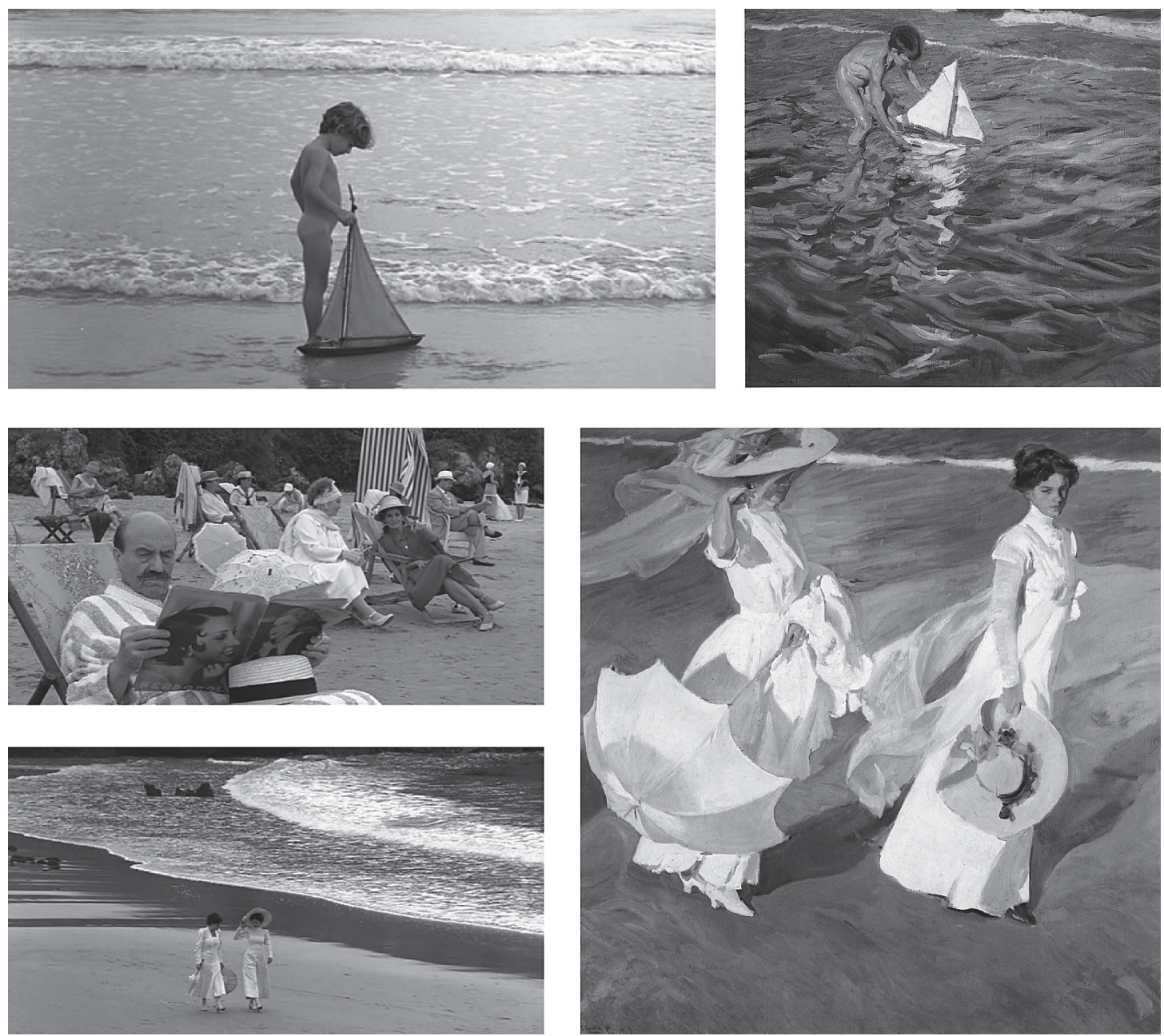

Fig. 5. Imágenes expresivas de la referencia hiperdiscursiva a Sorolla en Historia de un beso. La fotografía, la escenografía, el vestuario y los recursos de ambientación y caracterización de las escenas de playa rodadas en Barro, a la izquierda, evocan la estética del artista valenciano en El balandrito (1909) y Paseo a orillas del mar (1909), a la derecha (Museo Sorolla).

labres, simboliza claramente el fin de una vida (un río) y la entrada en la inmensidad inescrutable (del mar).

Otro aspecto reseñable de los paisajes en las obras de Jose Luis Garci se revela en la intensa presencia de otras formas artísticas en los tres relatos, lo cual contribuye sin duda a ampliar la percepción estética de las localizaciones. Ello se produce de dos maneras complementarias: - presencia hipertextual ${ }^{27}$ de obras preexistentes, ya sean fílmicas, pictóricas o literarias ${ }^{28}$,

27 En términos de Gérard Genette, “toda relación que une un texto B (que llamaré hipertexto) a un texto anterior A (al que llamaré hipotexto) en el que se injerta de una manera que no es la del comentario". GENETTE, Gérard, Palimsestos. La literatura en segundo grado, Taurus, Madrid, 1989, 519 pp., cf. p. 14.

28 Esta presencia hipertextual se encuentra asimismo en escenas rodadas fuera de nuestro ámbito geográfico de destacando, en el caso de las escenas rodadas en el concejo de Llanes, la cita de Calderón de la Barca en El abuelo, señalada más arriba.

- referencias hiperdiscursivas ${ }^{29}$ mediante el cine a modos expresivos de otros lenguajes ar-

estudio: por ejemplo, referencias fílmicas como las películas proyectadas en el Bar España de You're the one; musicales: entre otras, la primera Gymnopédie de Erik Satie en El abuelo y los fragmentos de ópera en You're the one; pictóricas, por ejemplo Las Meninas de Velázquez o pinturas postimpresionistas en los escenarios de Historia de un beso; e igualmente literarias, siendo de interés las citas de Shakespeare en El abuelo y la lectura de La Regenta clariniana en Historia de un beso. En cuanto al cine, tanto las reflexiones de los personajes sobre su naturaleza artística e influencia social en Your're the one como las proyecciones en el Bar España constituyen un magnífico homenaje metadiscursivo (el cine hablando del cine) por parte del director.

$29 \quad$ La noción de hiperdiscurso se refiere a los lenguajes construidos a partir de otros (discursos de discursos) 
tísticos, de lo cual resulta muy ilustrador cómo en Historia de un beso la fotografía, la escenografía, el vestuario y demás recursos de ambientación y caracterización concuerdan con las estéticas pictóricas modernista e impresionista, tanto que algunos planos parecen reproducir obras pictóricas. De ello son ejemplo las escenas veraniegas que, filmadas en la playa de Barro, adaptan a la luz cantábrica el reconocible estilo luminista-impresionista de Joaquín Sorolla y sus correspondientes instantáneas del esparcimiento y disfrute del "baño de ola". Participan de esta particular estética el rosario de arenales enlazados de Barro a Celorio, a cobijo entre salientes de tierra muy recortados, de altura variable, y castros o islotes desgajados del frente acantilado. El conjunto dibuja un entorno pintoresco, objeto de atención por parte del ámbito intelectual y de la Administración desde la consolidación turística de la comarca (véase Cuadro III), resultando así apropiado para la escena playera de época (véase figura 5).

\section{Conclusión}

El cine de José Luis Garci, apoyado en el trabajo de Gil Parrondo, ha contribuido a difundir de manera sugestiva el paisaje de la costa oriental de Asturias. Aprovecha de un modo original y consciente la singularidad del territorio llanisco, con su remarcable diversidad de componentes naturales, rurales y urbanos de reconocido valor patrimonial que contribuyen con densidad semántica a la construcción de los relatos (en los casos tratados, de carácter dramático-trágico). Las obras rodadas en este sector litoral, valiéndose asimismo de las ambientaciones históricas, inciden en un conjunto de atributos que invitan a la visita, al descubrimiento, al deleite contemplativo o al reposo. Lo hacen con una fotografía elaborada, ofreciendo una esmerada composición tan pronto dotada de cierto pintoresquismo como reflejando la exuberancia y excepcionalidad del paisaje, donde el tiempo atmosférico y sus variaciones, propias del clima oceánico, juegan también un papel importante en el relato. El director con-

como sucede con el cine, cuya enunciación suele presentar elementos propios de la narración, de la fotografía, de la música, etc. Profundícese sobre la noción en MILLÁN BARROSO, Pedro Javier, Cine, flamenco y género audiovisual. Enunciación de lo trágico en las películas musicales de Carlos Saura, Alfar, Sevilla, 2009, 432 pp. cede importancia de la luz "tamizada y tenue, que permite rodar una gama de colores suaves" en este escenario real. Las obras transmiten una visión poética, sosegada o idílica del espacio rural y natural, pero también, en ocasiones, inquietante, impactante y sublime, que Garci, al igual que una parte del público que él busca, en posesión de una elevada capacidad de interpretación de la imagen -más allá de los tópicos de la divulgación geográfica-, encuentra en el territorio asturiano, incluso con cierta connotación identitaria ${ }^{30}$. En efecto, Garci acude también a la costa asturiana evocando un origen familiar que se asocia a otros ritmos, modos de vida y escenarios; busca "emocionar al público, hablarle en primera persona y que se vea retratado" $^{31}$. La imagen del territorio llanisco se erige, en definitiva, en elemento fundamental de la estética y del mensaje en El abuelo, You're the one e Historia de un beso al tiempo que estas obras avivan y completan el imaginario popular acumulado.
30 CUARTAS, Javier, “José Luis Garci elige 'El abuelo', de Galdós, un canto al honor y a la tolerancia, para volver a TVE", en El País, Madrid, 18 de octubre de 1997, recuperado de http://elpais.com/diario/1997/10/18/ radiotv/877125601_850215.html [consultado el 30/10/2016]; SÁNCHEZ-BIOSCA, Vicente, "Paisajes, pasajes y paisanajes de la memoria. La historia como simultaneidad en la comedia española de los noventa", en Archivos de la filmoteca: Revista de estudios históricos sobre la imagen, n³9, Valencia, 2001, pp. 54-67, cf. p. 55; MARTÍNEZ EXPÓSITO, Alfredo, "La marca Asturias en el cine español: de Volver a empezar a Vicky Cristina Barcelona”, en Actas del II Congreso Ibero-Asiático de Hispanistas (Kioto, 2013), Servicio de Publicaciones de la Universidad de Navarra, Pamplona, 2014, pp. 341-355, cf. pp. 341-351.

31 MONJAS, Ch.L., "Entrevista. José Luis Garci", en La Voz de Galicia, A Coruña, 22 de octubre de 2002, recuperado de http://www.lavozdegalicia.es/hemeroteca/2002/10/22/1287763.shtml [consultado el 30/10/2016]; OLLERO LÓPEZ, Daniel Jerónimo, “Entrevista ...", opus cit.; MARTÍNEZ EXPÓSITO, Alfredo, "La estetica ...", opus cit. 